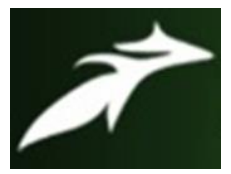

RAFAEL BANPURA UMDOR et al, International Journal of Advances in Agricultural Science and Technology,

Vol.7 Issue.11, November-2020, pg. 78-83

ISSN: 2348-1358

Impact Factor: 6.057

NAAS Rating: 3.77

\title{
TECHNOLOGICAL GAP IN RECOMMENDED CULTIVATION PRACTICES OF POTATO GROWERS IN EAST KHASI HILLS DISTRICT OF MEGHALAYA
}

\author{
RAFAEL BANPURA UMDOR ${ }^{1}$; Dr. SAYED H. MAZHAR ${ }^{2}$; Dr. JAHANARA ${ }^{3}$ \\ (M.Sc. Scholar); (Associate Professor); (Head of Department) \\ Department of Agricultural Extension \& Communication \\ Sam Higginbottom University of Agriculture, Technology \& Sciences, Prayagraj (211007) \\ DOI: 10.47856/IJAAST.2020.v07i11.011
}

\begin{abstract}
This study has been conducted to find out the technological gap in recommended cultivation practices of the potato growers in order to understand the extent of the difference between the traditional and nontraditional practices practiced by the local farmers in the district. The aforementioned study was conducted in East Khasi Hills district in the year 2020. A descriptive research designed was applied for this study. The primary data was collected from 120 respondents by personal interview method using pre-structure interview schedule. After the analysis of the data, it was observed that, maximum number of the respondents (38.30\%) were having medium level of extension contact and majority of the potato growers $(58.00 \%)$ belonged to high level of over-all technological gap category. It indicates that a sum number of the population had incorporated the new technologies while others have still yet to adopt and use the new recommended potato cultivation. The socioeconomic variables associated with the respondents, such as age, land holding, education, annual income and mass media exposure, extension contact and personal contact were negatively and significantly associated with the overall technological gap. The above results compel the research and extension system to work on the gaps and negative relationship in a pragmatic way.
\end{abstract}

Keywords: Growers, Gap, Technological, Potato, Recommended

\section{Introduction}

The Khasi tribal farmers of Meghalaya grow potato as an important cash crop. This crop is grown over 18,000 ha, which is about $8 \%$ of the net cultivated area in the state. Potato cultivation in the state however is primarily confined to the central plateau consisting of two hill districts, i.e., East and West Khasi Hills districts, which are primarily inhabited by the Khasi tribe. These two hill districts cover about $95.75 \%$ of the total land under potato and produce about $95-96 \%$ of the total potato production $(161,113 \mathrm{t})$ in the state. The introduction and knowledge of new and improved methodologies and technologies has been one of the sectors which have not been properly defined in the State. This study is implemented in order to ascertain the rate and proper understanding of the knowledge level of the farmers in comparison with the recommended adoption practices disseminated by the State Agricultural Department for 


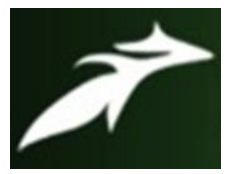

RAFAEL BANPURA UMDOR et al, International Journal of Advances in Agricultural Science and Technology, Vol.7 Issue.11, November-2020, pg. 78-83

ISSN: 2348-1358

Impact Factor: 6.057

NAAS Rating: 3.77

the improved production and productivity in order for the potato farmers to increase their profit from their produce.

\section{Method}

Descriptive research design was used for the present study, the major purpose of descriptive research is description of the state of affairs as it exists at present. Descriptive research design was followed, since the present study is fact-finding and present description of the respondents as well as the area. Multi stage sampling was followed for the present study for the selection of samples required. East Khasi Hills District has been selected purposively for the research work since it is one of the major districts in the State where potato cultivation is popularly practiced by the local farmers. There are 11 blocks in East Khasi Hills District out of which Khatarshnong Laitkroh C\&RD Block was selected purposively because maximum area is under potato cultivation. The data was collected personally by the researcher through pre-tested interview schedules, discussion method. The primary data was collected with the help of interview schedule, designed especially in light of the objectives set up for the study. Secondary data was collected from available reports, journals, etc. Appropriate statistical tools was used for the study.

\section{Objectives of the study:}

1. To find out the socio-economic characteristics of the respondents.

2. To understand the extent of technological gap in recommended cultivation practices of the respondents.

\section{Review of Literature}

Sharma, (2012) reported that the average technological gap under medium land condition was $45.44 \%$. Out of the 27 identified cropping patterns, the average technological gap of 10 cropping patterns under medium land condition was lower than the average figure for medium land condition. By and large, the technological gap of the crops in the patterns was moderate to high.

Kumar (2014) indicated that the crop technology demonstration has given a good impact over the farming community as they were motivated by recommended technology applied in the demonstration fields. Data further indicated that yield of mustard in following years increased successively within each variety. This clearly suggests the positive impact of demonstration over farmer's practices. The increase in grain yield under demonstration was 14.13 to $21.77 \%$ over 


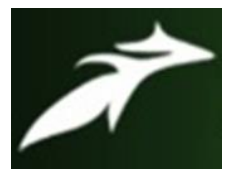

RAFAEL BANPURA UMDOR et al, International Journal of Advances in Agricultural Science and Technology, Vol.7 Issue.11, November-2020, pg. 78-83

ISSN: 2348-1358

Impact Factor: 6.057

NAAS Rating: 3.77

farmer's local practices. On an average $17.81 \%$ yield advantage was recorded under demonstrations carried out with improved cultivation technology as compared to farmer's traditional way of Chickpea cultivation.

Singh et al., (2017) found that the technology gap observed may be attributed to the variability in edaphic and climatic factors. The technology index (\%) was varied from $6.87-13.29 \%$ with an average of $10.08 \%$. Technology index was recorded to be decreased over the successive years of study the successive decreased value of technology index reflected the feasibility of the demonstrated technology in agro - climatic condition of eastern Uttar Pradesh.

Pandey (2018) that majority of the respondents had medium level of technology gap in practicing recommended cultivation practices of cauliflower. There were $3 \%$ and $44.4 \%$ respondents who had low and high level of technological gap in adopting recommended practices. It can be concluded that the overall technology gap against recommended cultivation practices accounted for $30.06 \%$.

Yadav et al., (2020) found that the technological gap of different package of practices with their mean and order to rank. The important package of practices on which they were having high technological gap were precaution in using (59.84\%) seed and sowing management followed by $(54.12 \%)$ fertilizer management, (42.19)plant protection management, (38.62\%) weed management, (38.54\%) field preparation, (35.97\%) harvesting management, $(33.75 \%)$ irrigation management and $(33.74 \%)$ storage management. Thus, it can be concluded that majority of the chickpea Growers were having high technological gap with respect to seed and sowing management $(59.84 \%)$ followed by fertilizer management $(54.12 \%)$ plant protection management $(42.19 \%)$ and whereas less than fourth of gram growers $(38.62 \%)$ were having low technological gap with respect to weed management.

\section{Results and Discussion}

The data collected during the study in regards to socio- economic status, it was observed that 44.17 per cent of the respondents belonged to the middle age group, 54.17 per cent were female, 76.67 of the respondents followed traditional religion (niam-tre). 55 per cent of the respondents had primary education, 55 per cent were fully dedicated to farming, 93.34 per cent belonged to nuclear family, 61.67 per cent of the respondents had family members less than 5, 48. 34 per cent had low annual income, 55 per cent of the respondents lived in cemented houses. 52.50 per cent had land holding of more than 0.5 hectares. 


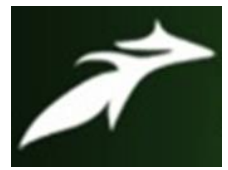

RAFAEL BANPURA UMDOR et al, International Journal of Advances in Agricultural Science and Technology,

Vol.7 Issue.11, November-2020, pg. 78-83

ISSN: 2348-1358

Impact Factor: 6.057

NAAS Rating: 3.77

Table 1 Distribution of the respondents based on Level of contact with extension personnel.

\begin{tabular}{|c|l|l|l|}
\hline S.No & Category & Frequency & Percentage \\
\hline 1 & Low (7-10.66) & 35 & 29.20 \\
\hline 2 & Medium (10.64-14.30) & 46 & 38.30 \\
\hline 3 & High (14.40-18) & 39 & 32.50 \\
\hline & Total & 120 & 100.00 \\
\hline
\end{tabular}

Table 1 shows that maximum number of the respondents (38.30\%) were having medium level of extension contact, followed by high (32.50\%) and low (29.20\%) level of extension contact respectively. Similar findings was also reported by Deshmukh et al. in (2007).

Table 2. To understand the extent of technological gap in recommended cultivation practices of the respondents

\begin{tabular}{|l|l|l|l|}
\hline Statement & Fully correct & $\begin{array}{l}\text { Partially } \\
\text { correct }\end{array}$ & Not correct \\
\hline Time of sowing & $91(75.84)$ & $19(15.84)$ & $10(8.34)$ \\
\hline Use of high yielding varieties & $33(27.5)$ & $77(64.17)$ & $10(8.34)$ \\
\hline Time of harvesting & $61(50.84)$ & $54(45)$ & $5(4.17)$ \\
\hline Method of sowing & $87(72.5)$ & $24(20)$ & $9(7.5)$ \\
\hline Plant to plant spacing distance & $85(70.84)$ & $28(23.34)$ & $7(5.84)$ \\
\hline Row to row spacing distance & $82(68.34)$ & $20(16.67)$ & $18(15)$ \\
\hline Land Preparation & $107(89.17)$ & $3(2.5)$ & $10(8.34)$ \\
\hline Weeding time & $7(5.84)$ & $77(64.17)$ & $36(30)$ \\
\hline
\end{tabular}

The data presented in the table 1, revealed that majority of the respondent potato growers $(58.00$ $\%$ ) belonged to high overall technological gap category, followed by 31.00 per cent of 


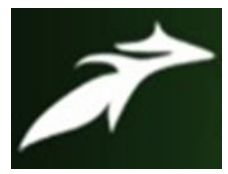

RAFAEL BANPURA UMDOR et al, International Journal of Advances in Agricultural Science and Technology, Vol.7 Issue.11, November-2020, pg. 78-83

ISSN: 2348-1358

Impact Factor: 6.057

NAAS Rating: 3.77

respondent who belong to medium overall technological gap categories and lastly, the low overall technological gat category at 11.00 per cent. a majority of 75.84 per cent of the respondents are fully correct about the tie of sowing, About 64.17 per cent of the respondents are partially correct about the high yielding varieties. 50.84 per cent of the respondents are fully correct about the time of harvest of potato. A majority of 72.5 per cent of the respondents are fully correct about the method of sowing. 70.84 per cent of the respondents were fully correct about the plant to plant spacing of potato. 68.34 per cent of the respondents were fully correct about the row to row spacing of potato. A majority of 89.17 of the respondents were fully correct about the land preparation of potato. 64.17 per cent of the respondents were partially correct about the weeding time of potato.

Table 3. Distribution of the respondents based on the technological gap towards potato cultivation.

\begin{tabular}{|l|l|l|l|}
\hline S.No & Category & Frequency & Percentage \\
\hline 1 & Low (15-18) & 13 & 11 \\
\hline 2 & Medium (19-21) & 37 & 31 \\
\hline 3 & High (22-24) & 70 & 58 \\
\hline & Total & 120 & 100.00 \\
\hline
\end{tabular}

More than 50 per cent was found in time of sowing (75.84\%), time of harvesting (50.84\%), method of sowing $(72.5 \%)$, plant to plant spacing $(70.84 \%)$, row to row spacing $(68.34 \%)$, land preparation $(89.17 \%)$. These factors might be due to high level knowledge of the respondents.

\section{Conclusion}

It is therefore concluded from the study that majority of the respondents falls under medium level of socio-economic. Majority of the respondents used technology correctly i.e., regarding the time of sowing, time of harvesting, method of sowing, plant to plant spacing, row to row spacing and land preparation. So, a good number of respondents had high level input about technological gap in response to the enquiries. Most of the respondents were well aware of the various cultivation practices of potato. 


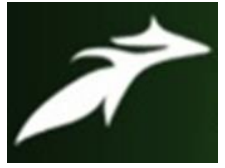

RAFAEL BANPURA UMDOR et al, International Journal of Advances in Agricultural Science and Technology,

Vol.7 Issue.11, November-2020, pg. 78-83

ISSN: 2348-1358

Impact Factor: 6.057

NAAS Rating: 3.77

\section{References}

[1]. Sharma J.K., 2012, Technological gap in major cropping patterns of small farms under medium land conditions in Nalbari District of Assam, J. Acad. Indus. Res. Vol. 1(7): 388-392.

[2]. Kumar. R. 2014, Assessment Of Technology Gap And Productivity Gain Through Crop Technology Demonstration In Chickpea, 2014, Indian J. Agric. Res.., 48 (2) 162-164, 2014, DOI: 10.5958/j.0976-058X.48.2.028

[3].Singh R; Dogra A.; Sarkar A; Saxena A.; Singh B., 2017, Technological gap constraint analysis and improved technologies for yield enhancement of barley (Hordeum Vulgare) and chickpea (Cicer arientinum) under arid conditions of Rajasthan, Indian Journal of Agriculture Sciences 88(2): 00-00, February 2018/Article.

[4]. Pandey. N; Kumar. N; Singh A.K.; Sharma. A. 2018, Technological Gap in Recommended Cultivation Practices of Cauliflower in Bokaro District of Jharkhand, 2018, International Journal of Current Microbiology and Applied Sciences ISSN: 2319-7706 Special Issue-7 pp. 5237-5241

[5]. Yadav, S; Rai; D.P. and Tripathi; U, K,. 2020 Technological gap in different practices of among chickpea growers in Satna district of Madhya Pradesh, India, 2020, Journal of Pharmacognosy and Phytochemistry 2020; 9(2): 1809-1813

[6]. Deshmukh,P.R.; Kadam, R.P.; Sindhe, V.N., 2007. Knowledge and adoption of agricultural technologies in Marathwada. Indian Res. J. Ext. Edu 7 (1): 40-42. 